\title{
Bazı baklagil yem bitkileri ile arpa karışım oranları belirlenerek yem verimi ve kalitesine etkisinin araştırılması
}

\author{
Seyithan SEYDoşoĞLU ${ }^{1}$, Nizamettin TURAN ${ }^{1}$ 1, C. Aylin OLUK ${ }^{2}$ \\ ${ }^{1}$ Siirt Üniversitesi Ziraat Fakültesi Tarla Bitkileri Bölümü, Siirt \\ ${ }^{2}$ Tarım ve Orman Bakanlığı, Doğu Akdeniz Tarımsal Araştırma Enstitüsü Müdürlüğü, Adana
}

Alınış tarihi: 14 Mayıs 2020, Kabul tarihi: 7 Temmuz 2020

Sorumlu yazar: Seyithan SEYDOŞOĞLU, e-posta: seyithanseydosoglu@siirt.edu.tr

\section{Öz}

Bu çalıșmanın amacı, yaygın (Vicia sativa L.) ve tüylü fiğ (Vicia villosa L.) ile arpa (Hordeum vulgare) karışım oranlarının belirlenerek yem verimi ve kalitesine etkisini incelemektir. Deneme, Siirt Üniversitesi Ziraat Fakültesi Tarla Bitkileri Bölümü deneme alanında kışlık olarak 2017-18 ve 2018-19 yetiştirme periyodunda iki yl süreyle yürütülmüştür. Çalışma Tesadüf Blokları Deneme Desenine göre 3 tekerrürlü olarak kurulmuştur. Yaygın fiğ, tüylü fiğ ve arpa bitkileri yalın ve arpa ile dört farklı karışım oranında (80:20, 60:40, 40:60, 20:80) ekilerek yeşil ve kuru ot verimi, asitte çözünmeyen lif (ADF), nötr çözünmeyen lif (NDF), sindirilebilir kuru madde oranı (SKM), kuru madde tüketim oranı (KMT), nispi yem değeri (NYD), ham protein oranı ve ham protein verimi değerleri belirlenmiştir. En yüksek yeşil ve kuru ot verimi yalın arpadan elde edilmiştir. Genel olarak arpanın girdiği karışımlarda, arpanın oranı artıkça yeşil ve kuru ot verimi de artmıştır. En yüksek ham protein oranı yaygın fiğde belirlenmiştir. Karışımdaki baklagillerin oranının artmasıyla ham protein oranı da artmıştır. Yalın ekilen baklagillerin ADF ve NDF oranı en düşük olmuştur. Karışımdaki baklagillerin oranı düştükçe ADF ve NDF oranının arttığı tespit edilmiştir. Sonuç olarak, yalın arpa ekimlerinin verimi yüksek olmasına rağmen, ot verimi ve ham protein verimi birlikte değerlendirildiğinde, \% 40 yaygın fiğ + \% 60 arpa karışımının ekilmesi önerilmektedir.

Anahtar kelimeler: Karışım oranı, kalite, verim, arpa, fiğ
Evaluation of the influence on forage yield and quality through determination barley mixture rates with some legume forage

\section{Abstract}

The objective of this research is to evaluate the effects of common (Vicia sativa L.) and hairy vetch (Vicia villosa L.) and barley (Hordeum vulgare) mixture rates on forage yield and quality. The experiment was conducted during winter season of 2017-18 and 2018-19 at the field of field crops research of Siirt University Faculty of Agriculture, Department of Field Crops. The study was randomized blocks design with 3 replications according to the trial pattern. Common vetch, hairy vetch and barley crop are established and barley with four different mixing ratios (80:20, 60:40, $40: 60,20: 80$ ). It was measured the green and hay yield, acid-insoluble fiber (ADF), neutral insoluble fiber (NDF), digestible dry matter rate, dry matter consumption rate, relative feed value, crude protein ratio and crude protein yield values. The maximum green and hay yield was produced from lean barley. Generally, as the ratio of barley increases in the mixture, the yield of green and hay yield has also increased. The highest crude protein ratio was obtained from common vetch. With the increase in the ratio of legumes in the mixture, the crude protein ratio was improved. The ADF and NDF ratio of lean legumes was minimum rate. It was determined that, the ratio of legumes in the mixture reduced, the ratio of ADF and NDF was increased. As a result, although the yield of barley planted alone is high, it is recommended to add $40 \%$ common vetch to planting material in terms of hay yield and quality.

Key words: Mixing ratio, quality, yield, barley, vetch 


\section{Giriş}

Siirt İli, ülkemizin Güneydoğusunda, Güneydoğu Anadolu Bölgesinin kuzeydoğusunda, Güneydoğu Torosların Güney eteklerinde kurulmuş olup, 41-42 boylamları ile 37-38 enlemleri arasında yer alır. İlin merkezi Dicle Nehrinin kollarından olan Botan ve Reşan Çayları arasında, yedi tepenin yamaçlarında kurulmuş ve günümüzde ovaya yayılmaya başlamıştır. İl genelinde, Siirt İli 2018 Yllı Çevre Durum Raporuna göre; $29.233,36$ ha çayır ve mera alanı bulunmakta olup, bu alan tüm araziler içerisinde \% 6.25 tekabül etmektedir (Anonim, 2020). Ancak, çayır-meraların bilinçsiz kullanımı sonucunda bu alanlar verimliliklerini büyük ölçüde kaybetmiştir. Bu nedenle ilde yem bitkileri tarımının arttırılması gerekmektedir.

Türkiye'nin farklı bölgelerinde yapılan baklagilbuğdaygil karışım çalışmaları mevcut olup, Kır ve ark. (2018) Kırşehir ekolojik koşullarında Macar fiği ile tahıl karışımlarında, en yüksek yaş, kuru ot verimleri ve sindirilebilir kuru madde verimi değerleri \%25 Macar fiği $+\% 75$ tritikale karışımından (sırasıyla 1677.1, 500.3 ve 315.9 $\mathrm{kg} / \mathrm{da}$ ), en yüksek ham protein oranı yalın ekilen Macar fiğinden (\% 18.8), en yüksek ham protein verimi \%75 Macar fiği $+\% 25$ tritikale karıșımından (\% $70.3 \mathrm{~kg} / \mathrm{da}$ ), en düşük ADF, NDF oranları ile en yüksek SKMO ve NYD değerleri yalın ekilen Macar fiğinden (sırasıyla \% 28.9, 49.5, 66.4 ve 125.3) elde edilmiştir. Yıldırım ve Özaslan-Parlak, (2016)
Çanakkale ekolojik koşullarında tritikalenin ile bazı tek yıllık baklagil yem bitkileri karışımlarında, en yüksek yeşil ot yalın baklada belirlenirken, kuru ot ise yalın tritikale ile tritikale: bakla (50:50) karışımlarında tespit edilmiştir. Genel olarak tritikalenin girdiği karışımlarda, tritikalenin oranı arttıkça kuru ot verimi de artmıştır. En yüksek ham protein oranı yalın ekilen baklagillerde, bunların arasında da baklada belirlenmiştir. Karışımdaki baklagillerin oranının artmasıyla ham protein oranı da artmıştır. Yalın ekilen baklagillerin NDF oranı en düşük olmuştur. Karışımlarda baklagillerin oranı düştükçe NDF oranının arttığı tespit edilmiştir. Ay ve Mut (2017), Yozgat ekolojik koşullarında yaygın fiğ ile bezelyenin arpa ve yulaf ile karışımda, kuru ot verimi, protein verimi, ADF ve NDF oranları açısından işlemler arasında önemli farklılıkların olduğu belirlenmiştir. Yllların birleştirilmiş ortalamalarına göre, kuru ot verimi, protein verimi, ADF ve NDF oranları sırasıyla $330.2 \mathrm{~kg} / \mathrm{da}, 58.7$ $\mathrm{kg} / \mathrm{da}, \% 30.53$ ve \%52.09 olarak belirlenmiștir.

$\mathrm{Bu}$ çalışmanın amacı, bazı baklagil yem bitkileri ile arpa karışım oranları belirlenerek yem verimi ve kalitesine etkisinin araştırılmasıdır.

\section{Materyal ve Yöntem}

Bu araştırma Siirt Üniversitesi Ziraat Fakültesi Tarla Bitkileri deneme alanında 2017-18 ve 2018-19 yetiştirme periyodunda iki yll süreyle yürütülmüştür.

Çizelge 1. Deneme alanları toprak özellikleri

\begin{tabular}{|c|c|c|c|}
\hline \multirow{2}{*}{ Toprak Özelliği } & \multirow{2}{*}{ Birim } & \multicolumn{2}{|c|}{ Değeri } \\
\hline & & $2017-2018$ & 2018-2019 \\
\hline Kil & $\%$ & 55.80 & 55.35 \\
\hline Kum & $\%$ & 36.30 & 37.80 \\
\hline Silt & $\%$ & 7.90 & 6.85 \\
\hline $\mathrm{pH}$ & & 7.98 & 7.90 \\
\hline Kireç & $\%$ & 13.0 & 12.5 \\
\hline Organik madde & $\%$ & 1.31 & 1.28 \\
\hline Alınabilir fosfor (P) & $\mathrm{kg} \mathrm{P}_{2} \mathrm{O}_{5} / \mathrm{da}$ & 4.3 & 4.1 \\
\hline Alınabilir potasyum (K) & $\mathrm{kg} \mathrm{K}_{2} \mathrm{O} / \mathrm{da}$ & 115 & 116 \\
\hline
\end{tabular}

Deneme alanlarının toprak özellikleri incelendiğinde, birbirine yakın topak yapısına sahip oldukları görülmektedir (Çizelge 1). Her iki yılda da toprakların tuzsuz, hafif alkali karakterde, orta kireçli, potasyum içeriklerinin yeterli düzeyde, organik madde kapsamı az ve alınabilir fosfor kapsamı ise çok az düzeyde olduğu tespit edilmiştir. Araştırma yerine ait bazı iklim verileri Çizelge 2'de verilmiştir. Ortalama sıcaklık ve nispi nem değerleri yıllar arasında benzerlik olduğu, toplam yağış miktarı ise 2018-19 sezonunun 2017-18 sezonundan daha fazla yağış düşmüştür.

Araştırmada materyal olarak, yaygın fiğ (Vicia sativa) Alınoğlu-2001 çeșidi, tüylü fiğ (Vicia villosa) Selçuklu-2002 çeşidi ve arpanın (Hordeum vulgare) Samyeli çeşidi kullanılmıștır. Araştırmada tarla denemeleri, Tesadüf Blokları Deneme Desenine göre 3 tekrarlamalı olarak kurulmuştur. Her iki yılda da, sonbaharda hazırlanan tarlaya ekimden önce alt gübre olarak $4 \mathrm{~kg} /$ da $\mathrm{N}$ ve $10 \mathrm{~kg} / \mathrm{da} \mathrm{P}_{2} \mathrm{O}_{5}$ olacak 
şekilde gübreleme yapılmıştır. Ekimler her iki yılda da Kasım ayının ikinci haftasında yapılmıştır. Yalın ekim ve karışımların tohumluk miktarı; çimlendirme testi yapilarak ve tohumluk safiyetleri göz önünde bulundurularak yaygın fiğ $12 \mathrm{~kg} / \mathrm{da}$, tüylü fiğ 13 $\mathrm{kg} / \mathrm{da}$ ve arpa $22 \mathrm{~kg} /$ da ekim normu dikkate alınmıştır. Dekara atılacak olan tohumluk miktarı, türlerin yalın ekimdeki tohum miktarının karışımda yer alan oranlarla çarpılması sonucu belirlenmiștir. Denemede parseller $2 \mathrm{~m}, 6$ siraya ve sira arası mesafe $25 \mathrm{~cm}$ (Anonim, 2019) olacak şekilde, markörle açılarak ve karışım türleri aynı sıraya karışık olarak elle ekilmiştir. Yaygın fiğg, tüylü fiğ, arpa yalın ve dörtlü karışım şeklinde 80:20, 60:40, 40:60, 20:80 oranlarında ekilmiştir.

Çizelge 2. Araştırma yerine ait uzun yıllar ve araştırma yılları bazı iklim verileri

\begin{tabular}{|c|c|c|c|c|c|c|c|c|c|c|c|c|c|}
\hline$\stackrel{\bar{\varpi}}{\stackrel{\Xi}{\Xi}}$ & 氖 & $\begin{array}{l}\vec{\pi} \\
\stackrel{\overrightarrow{0}}{J} \\
\vec{\omega}\end{array}$ & 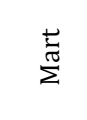 & $\begin{array}{l}\tilde{\pi} \\
\stackrel{\mathscr{n}}{Z}\end{array}$ & 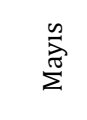 & 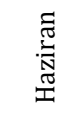 & $\underset{\stackrel{\Xi}{\Xi \Xi \Xi ~}}{\stackrel{\Xi}{\Xi}}$ & 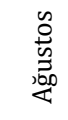 & $\underset{\text { 齐 }}{\grave{\lambda}}$ & 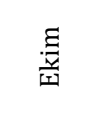 & 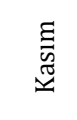 & $\begin{array}{l}\frac{y}{\bar{J}} \\
\text { 党 }\end{array}$ & $\sum_{\stackrel{5}{0}}^{\stackrel{0}{0}}$ \\
\hline \multicolumn{14}{|c|}{ Ortalama Sicaklık ${ }^{\circ} \mathrm{C}$} \\
\hline 2017 & 3.0 & 2.7 & 9.6 & 14.0 & 19.5 & 26.9 & 32.3 & 32.0 & 28.4 & 18.4 & 11.2 & 8.0 & 17.2 \\
\hline 2018 & 5.7 & 8.2 & 13.7 & 16.8 & 19.8 & 27.4 & 32.3 & 32.1 & 27.9 & 20.2 & 11.0 & 6.7 & 18.4 \\
\hline 2019 & 4.0 & 5.8 & 8.3 & 11.9 & 21.9 & 29.1 & 30.2 & 31.8 & & & & & 17.9 \\
\hline Uzun Yıllar & 2.8 & 4.4 & 8.7 & 14.1 & 19.5 & 26.2 & 30.6 & 30.1 & 25.2 & 18.1 & 10.3 & 4.7 & 16.2 \\
\hline \multicolumn{14}{|c|}{ Toplam Yağıș Miktarı (mm) } \\
\hline 2017 & 46.4 & 29.0 & 118.4 & 132.8 & 74.6 & 0.0 & 0.0 & 0.4 & 0.0 & 5.2 & 97.0 & 48.2 & 552.0 \\
\hline 2018 & 56.4 & 74.2 & 47.6 & 61.6 & 139.6 & 10.0 & 0.6 & 1.6 & 0.0 & 100.6 & 88.6 & 177.6 & 758.4 \\
\hline 2019 & 96.2 & 103.2 & 182.0 & 175.6 & 64.4 & 1.2 & 0.0 & 0.0 & & & & & 622.6 \\
\hline Uzun Yıllar & 72.9 & 89.9 & 98.9 & 96.7 & 59.5 & 9.7 & 3.1 & 2.3 & 4.7 & 47.9 & 77.8 & 83.6 & 647.0 \\
\hline \multicolumn{14}{|l|}{ Nispi Nem (\%) } \\
\hline 2017 & 65.9 & 64.9 & 63.9 & 59.5 & 51.7 & 29.5 & 19.0 & 19.0 & 19.1 & 34.6 & 64.4 & 65.2 & 46.4 \\
\hline 2018 & 70.5 & 67.7 & 55.9 & 47.6 & 59.2 & 31.7 & 20.1 & 21.4 & 23.0 & 47.8 & 76. & 82.0 & 50.2 \\
\hline 2019 & 72.5 & 66.9 & 63.5 & 66.8 & 41.8 & 26.5 & 23.0 & 20.5 & & & & & 47.7 \\
\hline Uzun Yillar & 70.5 & 65.6 & 60.3 & 57.3 & 49.2 & 34.0 & 26.8 & 26.1 & 31.0 & 47.2 & 62.2 & 70.1 & 50.0 \\
\hline
\end{tabular}

Hasat işlemleri; yalın ekimlerde baklagillerin çiçeklenme başlangıcl, arpanın başaklanma, karıșımlarda ise baklagillerin biçim zamanı olan \% 50 çiçeklenme dönemi esas alınarak yapılmıştır. Hasat edilen bitkiler, oda şartlarında kurutulmuş sonrasında $60{ }^{\circ} \mathrm{C}$ 'ye ayarlanmıș etüvde sabit ağırlığa ulaşana kadar kurutulmuştur. Daha sonra kurutulan örnekler ot değirmeninde ögütülerek (1 mm çapında olacak şekilde), kimyasal analizler için hazır hale getirilmiştir. Araştırmadaki yalın ekilen tür ve karışımların azot $(\mathrm{N})$ içeriği Kjeldahl yöntemi ile belirlenmiştir. Bulunan N değerleri 6.25 katsayısıyla çarpılmak suretiyle ham protein oranları (HPO) saptanmıştır (Kacar, 1972). Araştırmada incelenen tür ve karışımların HPO hesaplandıktan sonra kuru ot verimleriyle çarpılmış, ham protein verimi (HPV) belirlenmiştir. Nötr çözücülerde çözünmeyen lif (NDF) ve asit çözücülerde çözünmeyen lif (ADF) oranları Van Soest ve ark. (1991) tarafindan belirtilen yöntem kullanılarak belirlenmiștir. Kuru madde sindirilebilirlik değerleri sindirilebilir enerji miktarını tahmin etmek için belirlenmektedir. Bu amaçla; Oddy ve ark. (1983) tarafindan formülize edilen eşitlikle bitkilerin \%SKM oranları bulunmuştur (Sindirilebilir Kuru Madde (SKM) $=88.9-(0.779 \times \% A D F))$. Nisbi yem değerleri ise,
(SKM*KMT)/1.29 formülünü kullanılarak hesaplanmiştır (Sheaffer ve ark.,1995).

Veriler, iki yıl tekrarlanan Tesadüf Blokları Deneme Desenine göre JUMP istatistik paket programında varyans analizine tabi tutulmuş ve önemli çlkan ortalamaların karşılaştırılması LSD testine göre gruplandırılmıștır.

\section{Bulgular ve Tartışma}

Araştırmanın birinci yılında tüm uygulamaların ortalaması olarak elde edilen yeşil ot verimi (2953.2 $\mathrm{kg}$ ) ikinci yılda elde edilen verimden (3156.2 kg/da) istatistiksel olarak daha düşük olmuştur. İkinci yılda yeşil ot veriminin yüksek olması, yağıșların daha düzenli ve daha fazla düşmesinden kaynaklandığı söylenebilir (Çizelge 2). İki yıllık yeşil ot verimi değerlerinin birleştirilmiş analiz sonuçlarına göre; tür ve karışım oranlarının yeșil ot verimi istatistiksel olarak önemli derecede etkilemiş (Çizelge 3) ve iki yılın ortalaması olarak istatistiksel olarak farksız olan yalın arpa ile \%20TF + \%80 A karışımı diğer tür ve karışımlara göre istatistiksel olarak önemli derecede daha yüksek yeşil ot verimi vermiştir. $\% 80 \mathrm{TF}+\% 20 \mathrm{~A}$ ile $\% 80 \mathrm{YF}+\% 20 \mathrm{~A}$ karıșımları ise diğer tür ve karıșımlara göre istatistiksel olarak önemli derecede daha düșük yeșil ot verimi 
vermiştir. Yalın yetiştirilen türler arasında arpa, yaygın fiğ ve tüylü fiğe göre istatistiksel olarak önemli derecede daha yüksek yeșil ot verimi vermiştir (Çizelge 3). Karışımlarda, arpa oranının artması ile yeşil ot verimi artışı ortaya çıkmıştır. İlkbaharda yağışların arpanın hızlı gelişime katkıda bulunması ve bunun sonucunda arpanın rekabet gücünün yükselmesi arpanın veriminin artmasına neden olmuştur. Fiğ gibi tek yıllık baklagil yem bitkilerinde gövdenin sürünücü karakterde ve zayıf olması, ayrıca da yatması nedeniyle hasat zorlaşmakta, çürüme ve yaprak kayıplarından dolayı ot verimi düşmektedir (Anlarsal ve ark. 1996; Tan ve Serin, 1996). Elde edilen yeșil ot verimleri, Aşık (2006) bezelye ile arpa karıșımında, Kavut ve ark. (2014) Macar fiği ile İtalyan çimi karışımında, Kır ve ark. (2018) Macar fiği ile tahıl karıșımlarında elde ettikleri bulgulardan farklı olduğu tespit edilmiștir.
$\mathrm{Bu}$ farklılığın, kullanılan tür ve çeşitlerin yanında, iklim, toprak ve gübreleme gibi birçok faktörlerden kaynaklandığı söylenebilir.

Yeşil ot veriminde olduğu gibi, araștırmanın birinci yılında tüm uygulamaların ortalaması olarak elde edilen kuru ot verimi $(714.3 \mathrm{~kg} / \mathrm{da})$ ikinci yılda elde edilen verimden $(788.2 \mathrm{~kg} / \mathrm{da})$ istatistiksel olarak daha düşük olmuştur (Çizelge 3). İki yıllık kuru ot verimi değerlerinin birleştirilmiş analiz sonuçlarına göre, tür ve karışımlar kuru ot verimini istatistiksel olarak önemli derecede etkilemiş (Çizelge 3) ve iki yılın ortalaması olarak \%20TF + \%80A, \%20YF + $\% 80 \mathrm{~A}$ ile birlikte yalın ekilen arpa istatistiksel olarak yüksek kuru ot veriminin elde edildiği grubu oluştururken, \%80YF + \%20A ve \%80TF + \%20A karışımları ise en düşük kuru ot verimin elde edildiği araștırma konusu olmuştur.

Çizelge 3. Araştırmada incelenen yeşil ve kuru ot verimleri

\begin{tabular}{|c|c|c|c|c|c|c|}
\hline \multirow{2}{*}{ Karışım Oranı } & \multicolumn{3}{|c|}{ Yeşil Ot Verimi (kg/da) } & \multicolumn{3}{|c|}{ Kuru Ot Verimi (kg/da) } \\
\hline & 2018 & 2019 & Ortalama & 2018 & 2019 & Ortalama \\
\hline YF & 2653.3 & 2853.3 & $2753.3 e$ & 663.3 & 716.7 & $690.0 \mathrm{~cd}^{1}$ \\
\hline $\mathrm{TF}$ & 2930.0 & 3130.0 & $3030.0 \mathrm{~d}$ & 732.5 & 782.5 & $757.5 c$ \\
\hline $\mathrm{A}$ & 3670.0 & 3903.3 & $3786.7 a$ & 950.8 & 959.2 & $955.0 \mathrm{a}$ \\
\hline $80 \mathrm{TF}+20 \mathrm{~A}$ & 2123.3 & 2323.3 & $2223.3 f$ & 530.8 & 581.7 & 556.3de \\
\hline $60 \mathrm{TF}+40 \mathrm{~A}$ & 2553.3 & 2753.3 & $2653.3 \mathrm{e}$ & 569.6 & 691.7 & $630.6 \mathrm{~d}$ \\
\hline $40 \mathrm{TF}+60 \mathrm{~A}$ & 3166.7 & 3366.7 & $3266.7 c$ & 628.8 & 841.7 & $735.2 \mathrm{c}$ \\
\hline $20 \mathrm{TF}+80 \mathrm{~A}$ & 3475.3 & 3675.3 & $3575.3 \mathrm{ab}$ & 858.3 & 924.7 & 891.5ab \\
\hline $80 Y F+20 A$ & 2296.7 & 2496.7 & $2396.7 f$ & 607.7 & 624.2 & 615.9de \\
\hline $60 Y F+40 A$ & 2890.0 & 3090.0 & $2990.0 \mathrm{~d}$ & 655.8 & 767.5 & 711.7c \\
\hline $40 \mathrm{YF}+60 \mathrm{~A}$ & 3300.0 & 3500.0 & $3400.0 \mathrm{bc}$ & 791.8 & 872.5 & $832.2 b$ \\
\hline $20 Y F+80 A$ & 3426.7 & 3626.7 & $3526.7 \mathrm{~b}$ & 868.3 & 908.3 & 888.3ab \\
\hline Ortalama & 2953.2B & $3156.2 \mathrm{~A}^{+}$ & 3054.7 & $714.3 \mathrm{~B}$ & $788.2 \mathrm{~A}$ & 751.3 \\
\hline $\mathrm{CV}(\%)$ & \multicolumn{3}{|c|}{6.00} & \multicolumn{3}{|c|}{8.48} \\
\hline \multirow{3}{*}{ LSD } & $\mathrm{Y}$ & \multicolumn{2}{|c|}{$106.76^{* *}$} & \multicolumn{3}{|c|}{$42.57^{* *}$} \\
\hline & KO & \multicolumn{2}{|c|}{$213.82^{* *}$} & \multicolumn{3}{|c|}{$74.30^{* *}$} \\
\hline & İnteraksiyon & \multicolumn{2}{|c|}{ Ö.D } & \multicolumn{3}{|c|}{ Ö.D } \\
\hline
\end{tabular}

${ }^{1}$ Ortak küçük harf bulunan işlemler arasında istatistiki olarak fark yoktur ( $\left.\mathrm{p}<0.05\right)$

+ Yeşil ve kuru ot verimi bakımından yıllar arasında belirlenen fark istatistiki olarak önemlidir $(\mathrm{p}<0.05)$

Yalın yaygın ve tüylü fiğ parsellerinden elde edilen ortalama kuru ot verimi, bazı karışımlardan ve yalın arpa parsellerinden elde edilen verim değerlerinden istatistiksel olarak oldukça düşük bulunmuştur. $\mathrm{Bu}$ durum, genel olarak arpanın fiğe göre daha yüksek oranda kuru maddeyle birlikte daha yüksek karbonhidrat oranına sahip olmaları ve daha güçlü gelişme göstermelerinden kaynaklanmaktadır (Avcioğlu ve Avcioğlu, 1982; Hatipoğlu ve ark.1999; Gündüz, 2010). Ayrıca fiğlerde gövdenin zayıf ve sürünücü olması nedeniyle yatması yüzünden hasat döneminde kayıplar artarak, ot verimi düşmektedir. Araştırma sonucuna göre, yeşil ot veriminden elde edilen tür ve karışımların kuru ot verimleri de yüksek olmuştur. Diğer bir ifadeyle, kuru ot verimi ile yeşil ot verimi arasında olumlu bir ilişki vardır. Nitekim, Karakurt (2014)'ta bu ilişkiyi doğrulamaktadır.

Araștırmanın birinci yılının ADF oranı ortalaması (\%37.2), ikinci yılındaki ortalama değer (\%37.8) istatistiksel olarak önemsiz bulunmuş ve iki yıllık ortalama ADF oranı \%37.5 olarak belirlenmiştir. İki yıllık ADF oranı değerlerinin birleştirilmiş analiz sonuçlarına göre, tür ve karışımlar ADF oranını istatistiksel olarak önemli derecede etkilemiştir (Çizelge 4). Araştırmanın yürütüldüğü her iki yılda ve iki yıllık ortalamalarda en düşük ADF oranı yalın ekilen yaygın tüylü fiğden, en yüksek ise yalın ekilen arpadan (\%42.0) elde edilmiştir. Baklagil ve 
buğdaygillerin ADF içerikleri bakımından farklı olmalarının sebebi özellikle buğdaygillerde yaprak/sap oranın düşük olması ve çabuk olgunlaşmasıdır (Tan ve Menteşe, 2003).

Buğdaygiller ve baklagillerin ADF ve NDF gibi sindirimi belirleyen unsurlarının farklılığı anatomik yapılarından ve kimyasal kompozisyonlarından kaynaklanmaktadır. Buğdaygillerde baklagillere göre daha fazla hücre duvarı maddesi ve olgunlaşma ile birlikte hızlı bir lignin artışı görülür. Baklagiller ise genel olarak daha fazla hücresel bileșik ve daha az hücre duvarı oluşturan maddeye sahiptir. $\mathrm{Bu}$ nedenle baklagillerde olgunlaşma ile görülen besleme değeri kayıpları buğdaygillere oranla daha azdır (Cherney ve ark., 1985; Tan ve Menteşe, 2003). Nitekim araştırma bulgularımızda da arpanın, ADF ve NDF oranları bakımından daha yüksek değerler elde edilirken, bir baklagil bitkisi olan yaygın ve tüylü fiğlerden daha düşük değerler elde edilmiştir.

Araștırmanın birinci yılının NDF oranı ortalaması (\%49.5), ikinci yılındaki ortalama değer (\%50.1) istatistiksel olarak önemsiz bulunmuş ve iki yıllık otalama NDF oranı da \%49.8 olarak belirlenmiștir. Araștırmanın birinci yılındaki tür ve karıșımların NDF oranları \%45.2-54.4, ikinci yll \%45.8-55.0, iki yıllık bulguların birlikte analizinde \%45.5-54.7 arasında değişmiş olup, istatistiksel olarak önemsiz bulunmuştur.

Çizelge 4. Çalışmada incelenen ADF ve NDF oranları

\begin{tabular}{|c|c|c|c|c|c|c|}
\hline \multirow{2}{*}{ Karıșım Oranı } & \multicolumn{3}{|c|}{ ADF Oranı (\%) } & \multicolumn{3}{|c|}{ NDF Oranı (\%) } \\
\hline & 2018 & 2019 & Ortalama & 2018 & 2019 & Ortalama \\
\hline YF & 34.6 & 34.9 & $34.8 \mathrm{f}^{1}$ & 47.0 & 48.1 & 47.6 \\
\hline $\mathrm{TF}$ & 33.3 & 33.6 & $33.5 \mathrm{~g}$ & 47.4 & 48.1 & 47.7 \\
\hline $\mathrm{A}$ & 41.6 & 42.3 & $42.0 \mathrm{a}$ & 54.4 & 55.0 & 54.7 \\
\hline $80 \mathrm{TF}+20 \mathrm{~A}$ & 34.8 & 35.5 & $35.1 \mathrm{f}$ & 45.2 & 45.8 & 45.5 \\
\hline $60 \mathrm{TF}+40 \mathrm{~A}$ & 36.2 & 36.5 & 36.3de & 48.1 & 48.4 & 48.2 \\
\hline $40 \mathrm{TF}+60 \mathrm{~A}$ & 38.0 & 39.0 & $38.7 \mathrm{c}$ & 50.5 & 51.2 & 50.9 \\
\hline $20 \mathrm{TF}+80 \mathrm{~A}$ & 40.4 & 41.0 & $40.7 \mathrm{~b}$ & 52.2 & 52.5 & 52.3 \\
\hline $80 Y F+20 A$ & 35.0 & 35.7 & 35.3ef & 47.2 & 47.8 & 47.5 \\
\hline $60 \mathrm{YF}+40 \mathrm{~A}$ & 36.2 & 36.9 & $36.5 d$ & 48.7 & 49.0 & 48.9 \\
\hline $40 Y F+60 A$ & 38.7 & 39.1 & $38.9 c$ & 50.8 & 51.3 & 51.0 \\
\hline $20 \mathrm{YF}+80 \mathrm{~A}$ & 40.2 & 40.9 & $40.6 \mathrm{~b}$ & 52.9 & 53.4 & 53.2 \\
\hline Ortalama & $37.2 \mathrm{~B}$ & $37.8 \mathrm{~A}^{+}$ & 37.5 & 49.5 & 50.1 & \\
\hline CV $(\%)$ & \multicolumn{3}{|c|}{2.43} & \multicolumn{3}{|c|}{1.55} \\
\hline \multirow{3}{*}{ LSD } & $\mathrm{Y}$ & \multicolumn{2}{|c|}{ Ö.D } & \multicolumn{3}{|c|}{ Ö.D } \\
\hline & KO & \multicolumn{2}{|c|}{$1.05^{* *}$} & \multicolumn{3}{|c|}{$0.89 * *$} \\
\hline & İnteraksiyon & \multicolumn{2}{|c|}{ Ö.D } & \multicolumn{3}{|c|}{ Ö.D } \\
\hline
\end{tabular}

${ }^{1}$ Ortak küçük harfi bulunan işlemler arasında istatistiki olarak fark yoktur $(\mathrm{p}<0.05)$

${ }^{+}$ADF ve NDF oranları bakımından yıllar arasında belirlenen fark istatistiki olarak önemlidir $(\mathrm{p}<0.05)$

Çizelge 5. Çalışmada incelenen HPO ve HPV değerleri

\begin{tabular}{|c|c|c|c|c|c|c|}
\hline \multirow{2}{*}{ Karışım Oranı } & \multicolumn{3}{|c|}{ Ham Protein Oranı (\%) } & \multicolumn{3}{|c|}{ Ham Protein Verimi (kg/da) } \\
\hline & 2018 & 2019 & Ortalama & 2018 & 2019 & Ortalama \\
\hline YF & 18.23 & 18.90 & $18.57 \mathrm{a}$ & 121.18 & 135.72 & $128.45 \mathrm{a}^{1}$ \\
\hline $\mathrm{TF}$ & 16.48 & 15.55 & $16.01 \mathrm{c}$ & 120.74 & 121.71 & $121.22 \mathrm{ab}$ \\
\hline A & 8.13 & 9.03 & $8.58 f$ & 77.89 & 86.63 & $82.26 \mathrm{f}$ \\
\hline $80 \mathrm{TF}+20 \mathrm{~A}$ & 18.26 & 17.82 & $18.04 \mathrm{ab}$ & 96.89 & 103.51 & $100.20 \mathrm{de}$ \\
\hline $60 \mathrm{TF}+40 \mathrm{~A}$ & 17.21 & 17.57 & $17.39 \mathrm{~b}$ & 98.01 & 121.58 & $109.80 \mathrm{~b}-\mathrm{d}$ \\
\hline $40 \mathrm{TF}+60 \mathrm{~A}$ & 14.37 & 14.13 & $14.25 \mathrm{~d}$ & 90.57 & 118.92 & $104.74 \mathrm{~cd}$ \\
\hline $20 \mathrm{TF}+80 \mathrm{~A}$ & 9.30 & 10.00 & $9.65 \mathrm{e}$ & 79.83 & 92.42 & $86.13 f$ \\
\hline $80 Y F+20 A$ & 18.48 & 18.86 & $18.67 \mathrm{a}$ & 112.12 & 117.58 & $114.85 b c$ \\
\hline $60 Y F+40 A$ & 15.93 & 15.47 & $15.70 \mathrm{c}$ & 104.53 & 118.67 & $111.60 \mathrm{~b}-\mathrm{d}$ \\
\hline $40 Y F+60 A$ & 14.43 & 13.63 & $14.03 \mathrm{~d}$ & 114.32 & 118.97 & $116.65 a-c$ \\
\hline $20 Y F+80 A$ & 9.83 & 9.03 & $9.43 \mathrm{e}$ & 85.29 & 95.67 & $90.48 \mathrm{ef}$ \\
\hline Ortalama & 14.61 & 14.68 & & $100.12 \mathrm{~B}$ & $102.85 \mathrm{~A}^{+}$ & \\
\hline \multirow[t]{2}{*}{$\mathrm{CV}(\%)$} & \multicolumn{3}{|c|}{5,19} & \multicolumn{3}{|c|}{10.19} \\
\hline & $\mathrm{Y}$ & \multicolumn{2}{|c|}{ Ö.D } & \multicolumn{3}{|c|}{$5.32^{* *}$} \\
\hline \multirow[t]{2}{*}{ LSD } & KO & \multicolumn{2}{|c|}{$0.89 * *$} & \multicolumn{3}{|c|}{$12.60^{* *}$} \\
\hline & İnteraksiyon & \multicolumn{2}{|c|}{ Ö.D } & \multicolumn{3}{|c|}{ Ö.D } \\
\hline
\end{tabular}

1Ortak küçük harfi bulunan işlemler arasında istatistiki olarak fark yoktur $(\mathrm{p}<0.05)$

+Ham protein oranı ve ham protein verimi bakımından yıllar arasında belirlenen fark istatistiki olarak önemlidir ( $\mathrm{p}<0.05)$. 
Araştırmada belirlenen ham protein oranlarına yapılan varyans analizi sonucunda, yıllar arasında farklılık bulunmazken, tür ve karışımlar ham protein oranını istatistiksel olarak önemli derecede etkilemiştir (Çizelge 5). İki yılın ortalaması olarak saf ekilen yaygın ve tüylü fiğin diğer tür ve bazı karışımlara göre istatistiksel olarak önemli derecede daha yüksek ham protein oranı göstermiştir. Ayrıca, yaygın ve tüyle fiğin arpa ile karışımında, fiğlerin oranı artıkça ham protein oranı da artmıştır. Kır ve ark. (2018) Macar fiğ ile tahıl, Seydoşoğlu ve Bengisu (2019) yem bezelyesi ile tritikale, Önal-Aşçı ve ark. (2020) Macar fiği ve kolza karıșımlarında, karıșımda yer alan baklagillerin oranının artması ile elde edilen otun ham protein oranında istatistiksel olarak artış meydana geldiğini bildirmişlerdir.

Araştırmada incelenen tür ve karışımların ikinci yıldaki ham protein verimlerinin ortalaması (111.94 $\mathrm{kg} / \mathrm{da}$ ), birinci yl ham protein verimi ortalamasından $(100.12 \mathrm{~kg} / \mathrm{da})$ istatistiksel olarak önemli derecede daha yüksek olmuş ve iki yıllık ortalama ham protein verimi değeri $106.03 \mathrm{~kg} / \mathrm{da}$ olarak belirlenmiştir (Çizelge 5). İki yıllık ham protein verimi değerlerinin birleştirilmiş analiz sonuçlarına göre, tür ve karışımlar ham protein verimini istatistiksel olarak önemli derecede etkilenmiş (Çizelge 5) ve iki yılın ortalaması olarak yalın yaygın ile tüylü fiğ ve \%40YF + \%60A karışım diğer tür ve karışımlara göre istatistiksel olarak önemli derecede daha yüksek ham protein verimi vermiştir. Yalın arpa ve \%20TF + \%80A karışımı istatistiksel olarak birbirinden farklı olmayan ham protein verimi ortalaması göstermişlerdir. Ham protein verimi ile ilgili yapılan birçok araştırma mevcut olup; Önal-Aşçı ve Eğritaş (2017) Ordu koşullarında yaygın fiğ-tahıl karışımlarında 58.64$106.11 \mathrm{~kg} / \mathrm{da}$, Kır ve ark. (2018) Kırşehir koşullarında Macar fiği-tahıl karışımlarında 36.9$70.3 \mathrm{~kg} / \mathrm{da}$, Demiroğlu-Topçu ve ark. (2020) İzmir koşullarında değişik fiğ ve tahıl karıșımlarında 66$156 \mathrm{~kg} / \mathrm{da}$ arasında değiștiğini bildirmișlerdir. Elde edilen bulguların diğer araştırıcıların bulgularıyla farklılık göstermesi; çalıșmaların farklı ekolojilerde farklı tür ve çeşitlerle, farklı oranlarda hazırlanan karışımlarla yürütülmesinden kaynaklandığını söylemek mümkündür. Çünkü değişik tür ve karışımların kuru madde verimleri ve ham protein oranlarında ortaya çıkan farklılıklar, ham protein verimlerini de etkilemektedir.

Çizelge 6. Çalışmada incelenen sindirilebilir kuru madde ve kuru madde tüketimi değerleri

\begin{tabular}{|c|c|c|c|c|c|c|}
\hline \multirow{2}{*}{ Karışım Oranı } & \multicolumn{3}{|c|}{ Sindirilebilir Kuru Madde Oranı (\%) } & \multicolumn{3}{|c|}{ Kuru Madde Tüketimi Oranı (\%) } \\
\hline & 2018 & 2019 & Ortalama & 2018 & 2019 & Ortalama \\
\hline Yaygın Fiğ & 61.94 & 61.69 & $61.81 \mathrm{~b}$ & 2.55 & 2.50 & $2.52 \mathrm{~b}^{1}$ \\
\hline Tüylü Fiğ & 62.97 & 62.71 & $62.84 a$ & 2.53 & 2.50 & $2.52 \mathrm{~b}$ \\
\hline Arpa & 56.47 & 55.95 & $56.21 \mathrm{~g}$ & 2.21 & 2.19 & $2.19 \mathrm{f}$ \\
\hline $80 \mathrm{~T}+20 \mathrm{~A}$ & 61.79 & 61.27 & $61.53 \mathrm{~b}$ & 2.65 & 2.62 & $2.64 \mathrm{a}$ \\
\hline $60 \mathrm{~T}+40 \mathrm{~A}$ & 60.74 & 60.48 & $60.61 \mathrm{~cd}$ & 2.50 & 2.48 & $2.49 \mathrm{bc}$ \\
\hline $40 \mathrm{~T}+60 \mathrm{~A}$ & 59.01 & 58.49 & $58.75 \mathrm{e}$ & 2.37 & 2.34 & $2.36 \mathrm{~d}$ \\
\hline $20 \mathrm{~T}+80 \mathrm{~A}$ & 57.45 & 56.94 & $57.19 \mathrm{f}$ & 2.30 & 2.29 & $2.29 \mathrm{e}$ \\
\hline $80 Y+20 A$ & 61.64 & 61.12 & $61.38 \mathrm{bc}$ & 2.54 & 2.51 & $2.53 \mathrm{~b}$ \\
\hline $60 Y+40 A$ & 60.70 & 60.18 & $60.44 \mathrm{~d}$ & 2.46 & 2.45 & $2.46 \mathrm{c}$ \\
\hline $40 Y+60 A$ & 58.73 & 58.47 & $58.60 \mathrm{e}$ & 2.36 & 2.34 & $2.35 \mathrm{~d}$ \\
\hline $20 Y+80 A$ & 57.56 & 57.01 & $57.29 \mathrm{f}$ & 2.27 & 2.24 & $2.26 \mathrm{e}$ \\
\hline Ortalama & 59.91 & $59.48^{+}$ & & 2.43 & 2.40 & 2.42 \\
\hline CV (\%) & \multicolumn{3}{|c|}{1.19} & \multicolumn{3}{|c|}{1.24} \\
\hline \multirow{3}{*}{ LSD } & $\mathrm{Y}$ & \multicolumn{2}{|c|}{ Ö.D } & \multicolumn{3}{|c|}{ Ö.D } \\
\hline & KO & \multicolumn{2}{|c|}{$0.83^{* *}$} & \multicolumn{3}{|c|}{$0.04^{* *}$} \\
\hline & İnteraksiyon & \multicolumn{2}{|c|}{ Ö.D } & \multicolumn{3}{|c|}{ Ö.D } \\
\hline
\end{tabular}

10rtak küçük harfi bulunan işlemler arasında istatistiki olarak fark yoktur (p<0.05).

+Sindirilebilir kuru madde oranı ve kuru madde tüketimi bakımından yıllar arasında belirlenen fark istatistiki olarak önemlidir ( $<<0.05$ )

İncelenen tür ve karıșımların SKMO değerleri araştırmanın birinci yılında \%59.91, ikinci yılında \%59.48 ve istatistiksel olarak önemsiz, karıșım oranları ise istatistiksel olarak önemli bulunmuștur. Araştırmanın yürütüldüğü her iki yılın ayrı ayrı ve iki yıllık verilerin birlikte analizinde; en yüksek SKMO değerleri yalın tüylü fiğ, en düşük SKMO değeri ise yalın arpadan elde edilmiştir. Ayrıca yaygın ve tüylü fiğ karışımlarında, karışıma giren baklagillerin oranının artması ADF oranının azalması, dolayısıyla da SKMO değerlerinin artmasına yol açmıştır. Bu sonuç beklenen bir durumdur. Çünkü baklagiller buğdaygillerden daha yüksek ham protein ve daha düşük ADF, NDF içeriğine sahiptir. ADF içerdiği 
selüloz ve ligninden dolayı sindirilebilirlikle yakından ilgilidir (Linn ve Martin, 1999).

Araștırmanın birinci yılının KMT oranı ortalaması (\%2.43), ikinci yılındaki ortalama değer (\%2.40) istatistiksel olarak önemsiz bulunmuş ve iki yıllık ortalama KMT oranı \%2.42 olarak belirlenmiştir. İki yıllık KMT oranı değerlerinin birleştirilmiş analiz sonuçlarına göre, tür ve karışımlar KMT oranını istatistiksel olarak önemli derecede etkilemiștir (Çizelge 6). Araștırmanın yürütüldüğü her iki yılda ve iki yıllık ortalamalarda en düşük KMT oranı yalın ekilen arpa (\%2.19), en yüksek KMT oranı ise \%80TF + \%20A karışımından elde edilmiştir.

Çizelge 7. Araştırmada incelenen NYD değeri

\begin{tabular}{|c|c|c|c|}
\hline \multirow{2}{*}{ Karışım Oranı } & \multicolumn{3}{|c|}{ Nispi Yem Değeri } \\
\hline & 2018 & 2019 & Ortalama \\
\hline YF & 122.52 & 119.31 & $120.91 b^{1}$ \\
\hline $\mathrm{TF}$ & 123.68 & 121.45 & $122.57 \mathrm{~b}$ \\
\hline A & 96.66 & 94.58 & $95.62 \mathrm{f}$ \\
\hline $80 \mathrm{TF}+20 \mathrm{~A}$ & 127.32 & 124.41 & $125.86 \mathrm{a}$ \\
\hline $60 \mathrm{TF}+40 \mathrm{~A}$ & 117.56 & 116.24 & $116.90 \mathrm{c}$ \\
\hline $40 \mathrm{TF}+60 \mathrm{~A}$ & 108.64 & 106.30 & $107.47 d$ \\
\hline $20 \mathrm{TF}+80 \mathrm{~A}$ & 102.45 & 100.88 & $101.67 \mathrm{e}$ \\
\hline $80 Y F+20 A$ & 121.56 & 118.88 & $120.22 b$ \\
\hline $60 Y F+40 A$ & 115.98 & 114.19 & $115.08 \mathrm{c}$ \\
\hline $40 Y F+60 A$ & 107.62 & 106.02 & $106.82 d$ \\
\hline $20 \mathrm{YF}+80 \mathrm{~A}$ & 101.16 & 99.32 & $100.25 \mathrm{e}$ \\
\hline Ortalama & \multicolumn{3}{|c|}{$111.05 \mathrm{~B}^{+}$} \\
\hline CV (\%) & \multicolumn{3}{|c|}{1.94} \\
\hline LSD & $\begin{array}{c}\text { Y } \\
\text { KO } \\
\text { İnteraksiyon }\end{array}$ & \multicolumn{2}{|c|}{$\begin{array}{c}2.08^{*} \\
2.55^{* *} \\
\text { Ö.D }\end{array}$} \\
\hline
\end{tabular}

${ }^{1}$ Ortak küçük harfi bulunan işlemler arasında istatistiki olarak fark yoktur $(\mathrm{p}<0.05)$.

+ Nispi, yem değeri bakımından yıllar arasında belirlenen fark istatistiki olarak önemlidir $(\mathrm{p}<0.05)$.

Araştırmada incelenen tür ve karışımların birinci yıldaki NYD değeri ortalaması (113.20) ikinci yıl ortalamasına (111.05) göre istatistiksel olarak önemli derecede daha yüksek olmuştur (Çizelge 7). En yüksek NYD değeri \%80TF + \%20A karışımından elde edilirken, en düşük NYD ise yalın aradan elde edilmiştir. Yalın yaygın, tüylü fiğ ve $\% 80 Y F+\% 20 \mathrm{~A}$ karışımın istatistiksel olarak birbirinden farklı olmayan NYD değerleri göstermişlerdir.

\section{Sonuç}

Bazı baklagil yem bitkileri arpa karışım oranları belirlenerek yem verimi ve kalitesine etkisinin belirlenmesi amaciyla iki yll süreyle yürütülen bu çalışma sonucunda; her iki yılda da yalın arpa, $20 \mathrm{TF}+80 \mathrm{~A}$ ve $20 \mathrm{YF}+80 \mathrm{~A}$ işlemleri yüksek kuru ot verimine sahip olmasına rağmen, yalın TF, yalın YF ve $40 \mathrm{YF}+60 \mathrm{~A}$ işlemleri ham protein verimi bakımından üstün bulunmuşlardır. Araștırmadan elde edilen hem kuru ot hem de protein verimi birlikte değerlendirildiğinde, $40 \mathrm{YF}+60 \mathrm{~A}$ işleminin öne çıktığı anlaşılmaktadır. $\mathrm{Bu}$ nedenle benzer ekolojilerde, \% 40 yaygın fiğ+\% 60 arpa karışımının kuru ot amaciyla yetiştirilmesi önerilebilir.

\section{Kaynaklar}

Anonim, (2020). Siirt Valiliği Çevre ve Şehircilik İl Müdürlüğü. Siirt İli 2018 Yılı Çevre Durum Raporu 12.02.2020 tarihinde, https://webdosya.csb.gov.tr/ db/ced/icerikler/s--rt_-cdr2018 - 2019111509 4458. pdf) adresinden erişildi.

Anonim, (2019). Baklagil Yem Bitkileri Tarımsal Değerleri Ölçme Denemeleri Teknik Talimatı. T.C. Tarım ve Orman Bakanlığı Bitkisel Üretim Genel Müdürlüğü, 12.02.2020 tarihinde,https://www.tarimorman. gov.tr/BUGEM/TTSM/Belgeler/Duyuru\%20Belgel eri/2019/\%C3\%A7ay\%C4\%B1r\%20mera/baklagil \%20yem\%20bitkileri.pdf adresinden erișildi.

Aşık, F.F. (2006). Bezelye (Pisum sativum L.) ve arpa (Hordeum vulgare L.) karıșımlarında karıșım oranları ve biçim zamanlarının otun verimi ile kalitesi üzerine etkileri. Yüksek Lisans Tezi, Uludağ Üniversitesi Fen Bilimleri Enstitüsü, Bursa

Avcıoğlu, Ş., \& Avcıoğlu, R. (1982). Değişik karışım oranları ile biçim zamanlarının adi fiğ+yulaf hasıllarının verim ve diğer bazı özellikleri üzerine bir araştırma. Ege Üniversitesi Ziraat Fakültesi Dergisi, $19(2), 123-136$.

Anlarsal, A. E., Ülger, A. C. Gök, M., Yücel, C., Çakır, B., \& Onaç, I. (1996). Çukurova'da tek yıllık baklagil yem bitkisi + misır üretim sisteminde baklagillerin ot verimleri ile azot fiksasyonlarının saptanması ve mısır üretiminde azot kullanımını azaltma olanakları. Türkiye 3. Cayır-Mer'a ve Yem bitkileri Kongresi, Erzurum, 362-368.

Ay, İ., \& Mut, H. (2017). Yaygın fiğ ile yem bezelyesinin arpa ve yulaf ile karışımlarında uygun karışım oranının belirlenmesi. ÇOMÜ Ziraat Fakültesi Dergisi, 5(2), 55-62.

Cherney, J.H., Volanec, J.J., \& Nyquist, E.W. (1985). Sequential fiber analysis of forage as influenced by sample weight. Crop Science, 5(1), 1113-1115.

Demiroğlu-Topçu, G., Kır, B., Çelen, A.E., \& Kavut, T.Y. (2020) Değişik fiğ + tahıl karışımları için en uygun karışım oranı ve biçim zamanının belirlenmesi. ISPEC Tarım Bilimleri Dergisi, 4(2), 146-156.

Gündüz, T.E. (2010). Diyarbakır koşullarında karışım oranının Macar fiği (Vicia pannonica Crantz)+buğday (Triticum aestium var. aestium L.) karışımında ot verimi ve kalitesine etkisi. Yüksek 
Lisans Tezi, Çukurova Üniversitesi, Fen Bilimleri Enstitüsü, Adana.

Hatipoğlu, R., Çil, A., \& Gül, İ. (1999). Diyarbakır koşullarında karışım oranının fiğ+tritikale karışımında ot verimi ve ot kalitesine etkileri üzerinde bir araştırma. GAP 1.Tarım Kongresi, 2628 Mayıs, 667-674, Şanlıurfa.

Kavut, Y. T., Geren, H., Soya, H., Avcıoğlu, R., \& Kır, B. (2014). Karışım oranı ve hasat zamanlarının bazı yıllık baklagil yem bitkileri ile italyan çimi karıșımlarının kışlık ara ürün performansına etkileri. Ege Üniversitesi Ziraat Fakültesi Dergisi, 51(3), 279-288.

Kır, H., Karadağ, Y., \& Yavuz, T. (2018). The factors affecting yield and quality of hungarian vetch+cereal mixtures in arid environmental conditions. Fresenius Environmental Bulletin, 27(12A), 9049-9059.

Kacar, B. (1972). Bitki ve toprağın kimyasal analizleri II. Bitki analizleri. Ankara Üniversitesi Basımevi, Ankara s. 646

Karakurt, E. (2014). Bazı fiğ türlerinde verim ve verim komponentleri arasındaki ilișkilerin Path Analizi ile Değerlendirilmesi. Bilecik Seyh Edebali Üniversitesi Fen Bilimleri Dergisi, 1(1):10-16.

Linn, J.G., \& Martin, N.P. (1999). Forage quality Tests and Interpretations. $\quad 15.02 .2020 \quad$ tarihinde, https://www.extension.org/pages/68573/managi ng-dairy-nutrition-for-the-organic-herd:-foragetesting-and-interpreting-lab-analyses adresinden erişildi.

Seydoşoğlu, S., \& Bengisu, G. (2019). Effects of different mixture ratios and harvest periods on grass quality of triticale (xTriticosecale wittmack) -forage pea (Pisum sativum L.) intercrop. Applied Ecology And Environmental Research, 17(6),13263-13271.
Sheaffer, C. C., Peterson M. A., Mccalın M., Volene J.J., Cherney,J.H., Johnson K.D.,Woodward W.T. \& Viands D.R. (1995). Acid detergent fiber, neutral detergent fiber concentration and relative feed value, North American Alfalfa Improvement Conference, Minneapolis.

Oddy, V.H., Robards, G.E., \& Low, S.G. (1983). Prediction of in vivo dry matter digestibility from the fiber nitrogen content of a feed. In: Robards, G.E., Packham, R.G. (Eds.), Feed Information and Animal Production. Commonwealth Agricultural Bureaux, Farnham Royal, UK, pp. 395-398.

Önal-Așçı, Ö., \& Eğritaş, Ö. (2017) Yaygın fiğ-tahıl karışımlarında ot verimi, bazı kalite özellikleri ve rekabetin belirlenmesi. Tarım Bilimleri Dergisi, 23(2), 157-284.

Önal-Aşçı, Ö., Demirkol, G., \& Kaşko-Arıcl, Y. (2020). Macar fiği kolza karışımlarının ot verimi, kalitesi ve bitkiler arasındaki rekabet bakımından değerlendirilmesi. Akademik Ziraat Dergisi, 9(1), 119-128.

Van Soest, P. J., Robertson, J. B., \& Lew1s, B.A. (1991). Method for dietary fiber, neutral detergent fiber, and nonstarch polysaccharides in relation to animal nutrition. J. Dairy Sci., 74, 3583- 3597.

Tan, M., \& Serin, Y. (1996). Değișik fiğ + tahıl karıșımları için en uygun karışım oranı ve biçim zamanının belirlenmesi üzerine bir araștırma. Atatürk Üniversitesi Ziraat Fakültesi Dergisi, 27(4), 475-489.

Tan, M., \& Menteșe, Ö. (2003). Yem bitkilerinde anatomik yapı ve kimyasal kompozisyonun besleme değerine etkileri. Atatürk Üniversitesi, Ziraat Fakültesi Dergisi, 34(1), 97-103.

Ylldırım, S., \& Özaslan-Parlak, A. (2016). Tritikale ile bezelye, bakla ve fiğ karışım oranlarının belirlenerek yem verimi ve kalitesine etkileri. ÇOMÜ Ziraat Fakültesi Dergisi, 4(1), 77-83. 